\title{
PREFACE: AUTHORITY AND DEFINITION
}

The letters of Virginia Cary Hudson Cleveland (1894-1954), ${ }^{1}$ Beverly Kienzle's grandmother, illustrate the issues of authority and definition that have surrounded the act of preaching for women during the nearly twenty centuries of Christianity. Virginia taught at Calvary Episcopal Church in Louisville, Kentucky; she regularly instructed the Women's Auxiliary and adult Sunday school classes designed to prepare her audience for better appreciating the rector's sermon. Her letters contain occasional references to complaints about her teaching's encroaching either in time or in authority on the rector's message. Virginia also taught Sunday school classes at the Methodist church in Cloverport, Kentucky, where her family had a country house. Her audience included Methodists, Baptists, and two Jews, whose insights on the Hebrew Scriptures she treasured. Most were simple country folk who came to town on Sundays, attracted by the dynamic lessons of their ecumenical teacher. Virginia also gave religious instruction in another setting, the Goodwill Chapel in downtown Louisville; she called that instruction preaching. There she was the authorized voice; she even had her rector's permission. To her daughter she wrote: "At a church council meeting some weeks ago I was asked to be the Episcopal representative to the Goodwill Chapel for Lent. I soon learned that my responsibilities meant the whole shebang, including preaching on Ash Wednesday and Good Friday. . . . These people at the chapel are a forlorn folk who must at times feel that God has forgotten them. Our work is simple: to bring spiritual encouragement and assurance to them."Virginia's preaching was so well received that she was asked to deliver additional sermons. The chapel superintendent said to her, "The la-di-da words of some of the robed preachers do not go over down here. These are simple and plain people who want a simple truth."

Some of the women whose stories are told in this book spoke a simple 
truth and others a message embedded in figurative language; both groups found their modes of expression in the Scriptures. Some based their authority solely on divine inspiration; others were authorized by their communities and a few by the hierarchy of the dominant church. Their voices call for the examination of what constitutes preaching and for the recognition that preaching can be defined with and without restrictive categories. Broadly viewed, preaching is the delivering of a religious discourse-a sermon-by a preacher to an audience. More narrowly construed, the term preaching designates that the sermon is delivered by an authorized cleric within the context of a worship service or liturgy. ${ }^{2}$ That definition incorporates restrictive categories: the control over designation of the preacher and over time and space within the liturgy or worship service.

Throughout the twenty centuries of the Christian era, a narrow definition of preaching has served as an instrument for delegitimizing acts of religious discourse that fall within the bounds of the broader definition. The voices of women, saddled with accusations of theological and biological inferiority, have been especially constrained and delegitimized. Although prophesying has been recognized as an activity accessible to women, preaching generally has not. Restrictions have obstructed recognition of the spirit's voice when enunciated by a woman; the name preaching has been withheld to deny legitimacy or pronounced to issue condemnation.

Yet the women discussed in this volume participated in preaching, some within the narrow definition and some within the broader one. The label applied to their discourse and to the expression of their voices varies according to the perception of their right to authority. Their contemporaries may have wished either to sanction or to condemn these women; they bent the language to reflect their approval or condemnation of the women's actions. Instances of prophesying, teaching, or the like have sometimes been labeled preaching when they fell under suspicion. Women themselves have sometimes used language that reflected the boundaries of authority. Repeatedly women have been described, or have chosen to describe themselves, as prophesying, teaching, or performing some other authorized act when preaching was prohibited to them.

Despite the centuries of prohibitions grounded on Paul's injunctions against women teaching in the public assembly, many women throughout the history of Christianity have preached, claiming authority for themselves through the inspiration of the Holy Spirit and also finding alternate routes for expression such as writing, teaching, and singing. Some independentminded communities of men and women have recognized female voices as authoritative and have even adopted structures that grant authority to women's voices. The recurring presence of women's preaching attests to both the continuing struggle within Christianity over problems of authority and the indomitable spirit of women's voices. 
This book explores the diverse voices of Christian women who claimed the authority to preach and prophesy and analyzes their relationships to broader Christian communities from the second century to the twentieth. The essays vary somewhat in length for deliberate reasons: a lesser-known community such as the Moravians or one widely misunderstood such as the Cathars requires a lengthier explanation of its organizational background than do more familiar institutions or communities. Similarly, the essay on the figure of Mary Magdalene provides a transition from early to late antique and medieval Christianity and thus merits an extensive development of its subject.

The contributors to this volume are scholars in folklore, church history, social and political history, history of art, religion, literary criticism, and biblical studies. All take an interdisciplinary approach to their topics, transcending narrowly construed limits of academic disciplines in order to explore and elucidate the broad cultural context of their subjects. Similarly, their sources are extensive and varied, including Scripture, sermons, art, polemical literature, letters, diaries, chronicles, inquisitors' manuals, devotional works, and fiction.

The essays in this volume all break new ground. For the premodern period, they represent some of the first studies in the expanding research on women preachers and women's preaching. Even the exemplary Hildegard of Bingen has received little attention for her sermons, although she preached publicly with approbation. A new edition of her gospel homilies is being prepared and translated into English, and essays examining Hildegard's preaching are scheduled to appear. ${ }^{3}$ The connection medieval society made between a woman's preaching and demonic possession has also been brought to light in the case of Sigewize, a woman inspired by Hildegard and judged as possessed by a demon because of her desire to preach publicly. ${ }^{4}$ Other studies on medieval women's preaching were either published or being undertaken as this volume was being completed: an article on the preaching of Lollard women; an edition of Umiltà of Faenza's sermons and their translation into English; a major study on Birgitta of Sweden and an essay on her role as preacher and prophet; and a dissertation on gender and authority in late medieval preaching. ${ }^{5}$ Still other research on the sermons of medieval women has already been stimulated by the discussion around this volume.

For the modern period, existing research is more extensive, especially on the nineteenth century, but a focus on preaching in the field of women's history is still a neglected area. The eighteenth and nineteenth centuries witnessed a profusion of new denominations and sectarian movements among Protestants. Women preachers contributed to the birth and growth of these movements. Certainly they had predecessors in Anne Hutchinson (1591-1643), who was expelled from Massachusetts, and in the seventeenthcentury Quakers in England and America, but in the later period, women 
from both new and established denominations preached in greater numbers and sometimes with institutional sanction. Scholars have explored why these phenomena emerged in their respective periods, the significance of women's religious leadership for their theology and practice, and their relationship to modern women's rights campaigns that also took root during those centuries. ${ }^{6}$ Names of eighteenth- and nineteenth-century women who preached have become familiar in recent years. Among them are Sarah Osborn (b. 1714), religious instructor to whites and free blacks in eighteenth-century Rhode Island; Barbara Ruckle Heck (1734-1804), called the "Mother of American Methodism"; Jarena Lee $\left(1783-183^{6}\right)$, a preacher who challenged the African Methodist Episcopal Church to sanction her work; Mary Barritt Taft (1772-1851), a British Methodist whose preaching divided the Wesleyan Methodist Connexion; Sojourner Truth (ca. 1797-1883), emancipated slave, abolitionist, and independent preacher; Phoebe Palmer (1807-1874), holiness preacher and author; Mary Baker Eddy (1821-1910), founder of Christian Science; and Antoinette Brown, ordained a Congregationalist minister in 1853 .

Yet, although exemplary women have received increased scholarly attention in the last ten to fifteen years, their preaching and sermons generally have not been the focus of research. Many women have been studied more for their political campaigns than for their preaching and religious vision. Scholars, moreover, have often presented them as unique individuals. This volume is concerned with individual women but equally with the movements that fostered women's preaching and with placing women preachers within the history of Christianity. During the 1980 os and 199 os, increasing numbers of women have entered the Christian ministry, and they are producing literature directed toward contemporary women preachers and their preaching. These contemporary works on women's sermons, like the recent scholarship on modern women, generally have not examined the scope of women's preaching over the centuries and have not uncovered the extensive reach of historical precedent that is demonstrated in this book, with its panorama of women's preaching over the two millennia of Christianity. Although this volume is not a comprehensive history of women's preaching, it does take the first step toward creating a fuller view by illustrating both the persistence of women's voices and the consistency of the strategies used against them. It challenges the narrow definition of preaching that has constricted the study of women's voices and explores how alternative routes for expression such as prophecy and teaching fall within a larger view of what constitutes preaching. It also demonstrates how distinctions between preaching and related avenues of expression have been either blurred or sharpened in attempts to legitimize or delegitimize women's religious speech. Thus this volume establishes a broad and creative basis for recounting the history of women preachers and their sermons. 
The essays begin with a contemporary perspective that reflects on the analysis of women's preaching in the present and its relationship to the past. Elaine Lawless's introduction, "The Issue of Blood: Reinstating Women into the Tradition," draws on years of research focused on contemporary women's preaching, first in Pentecostal communities and more recently in mainline Protestant denominations. She asks how contemporary women's preaching can illuminate the past and, at the same time, how studying the past can reinforce women's claims to the right to preach in the present. Lawless's work listening to, recording, and analyzing actual sermons delivered by women differs from the research of other contributors to the volume, who reconstruct limited historical evidence to write a history of women's preaching. Nonetheless, Lawless draws significant parallels between women's sermons today and the writing of a history of preaching that includes women. Both are about reinstating women and their experiences into the tradition. Just as a woman's story (the story of the woman with an issue of blood) is omitted from the present-day lectionary but brought into one of the sermons Lawless cites, so too women's preaching has been excluded from the historical record but is being reinserted by the essays in this volume.

Elaine Lawless's look at contemporary women's preaching is balanced by Karen King's afterword, "Voices of the Spirit: Exercising Power, Embracing Responsibility," in which King reviews the questions posed by the essays in this volume and raises issues for contemporary scholars. King notes how key scriptural passages and biased notions of women's nature and rightful place have been used to attempt to silence women for centuries. Women, however, have developed means to claim their right to preach, employing other passages of scripture that justify their speaking, renaming their speech acts, challenging institutional restrictions, and creating alternative institutions. King demonstrates that comparison of the women preachers featured in this volume reveals a range of common strategies and convictions. She ends with questions that merit further scholarly research and highlights the new perspectives on Christianity, past and present, that the volume opens up.

Ten of the essays in this volume deal with Christianity before the Reformation. The essays of Karen King and Karen Jo Torjesen focus on early Christian communities. King introduces the conflicts over women's leadership in early Christian communities, and through her analysis of the Gospel of Mary (Magdalene) explores the nature of prophetic speech and its relationship to gender. Torjesen examines artistic representations of the female orans, a woman depicted in a posture of prayer and previously interpreted as a symbol of the church or of the soul. Torjesen argues that viewers in antiquity would have associated the orans with women's praying, prophesying, and preaching, and she places examples of those activities within the broader interpretive framework of women's participation in early Christian worship.

Katherine Ludwig Jansen's essay on Mary Magdalene builds a bridge from 
early and late antique to medieval Christianity. Jansen traces the confusion in Magdalene's identity, concretized by Gregory the Great, and demonstrates how interpretations of Magdalene's preaching and vocation as apostolorum apostola encapsulate conflicting and ambiguous views toward the phenomenon of a preaching woman. Magdalene was hailed as the proclaimer of Jesus' resurrection and the evangelizer of Gaul: some described her as the recipient of a special dispensation from the Pauline ban on women's preaching; others simply and enthusiastically praised her. Although the church prohibited women's preaching, Magdalene appeared as a preaching figure in sermons, art, liturgy, and popular and sacred literature.

Dissident groups in medieval Christianity allowed women greater participation in religious life, as described in the essays by Beverly Mayne Kienzle and Anne Brenon. Kienzle analyzes the evidence for the preaching of Waldensian women and the patterns of rhetoric and thought discernible in the polemical literature directed against the Waldensians in the late twelfth and early thirteenth centuries. Brenon traces the historical evidence for women's participation in Catharism and defines the pastoral and sacerdotal functions of women in the Cathar churches of Languedoc. Inquisition records attest to the presence of women among preachers and believers alike.

Within orthodox circles women found ways to express their voices by exploiting alternatives to preaching: primarily teaching and prophecy. Nicole Bériou explores legislation prohibiting women from preaching and demonstrates how they nevertheless developed and received praise for their role as teachers of the faith. Carolyn Muessig analyzes the lines demarcating preaching and prophecy and tells the story of a famous male preacher who advocated singing as an acceptable channel of expression for cloistered women, one that he described in terms like those used for the activity of preaching. Darleen Pryds and Roberto Rusconi focus on medieval Italy, where exemplary women, biblical figures and later saints, expanded the boundaries of practice and imagination. Pryds brings to life Rose of Viterbo, a teenage Italian laywoman of the thirteenth century who preached publicly in her native city with the knowledge and approbation of church officials. The two vitae circulated as part of her canonization process portray her speaking publicly, and the second-a fifteenth-century text-describes her speech specifically as preaching. Rusconi analyzes the Italian iconography of women known generally through hagiographical literature: early saints such as Mary Magdalene, Cecilia, and Catherine of Alexandria, and medieval figures such as Rose of Viterbo, Umiltà of Faenza, and Catherine of Siena. The artistic representation of these exemplary women documents the public recognition of their preaching as a mark of holiness.

Of the eight essays examining the period from the Reformation to the twentieth century, two focus on the Reformation, when Christians struggled with questions of individual and institutional authority, the distinctions 
between clergy and laity, and the claims of established and emergent denominations. Women's preaching was one aspect of these broader issues. Edith Dolnikowski investigates how John Foxe's influential Acts and Monuments used stories of women who publicly proclaimed their faith to demonstrate the vital importance of reading and preaching the Gospel in the vernacular. The emphasis on women's voices underscored the tenet that any Christian, male or female, lay or clergy, could and should offer public witness. The seventeenth-century Catholic Reformation provides the context for Linda Lierheimer's treatment of the apostolate of the French Ursulines. The Ursulines were among the European women who began to teach, nurse, and missionize, thereby creating new models of public, female, religious activity. Although they never officially claimed the role of preacher, the Ursulines assumed public religious authority when they taught and attracted followers to their chapels. Their activities, alternately termed preaching and teaching, illustrate how closely religious teaching approximates preaching and how the boundaries between the two could be purposefully blurred to create a space for female voices.

Two essays bring to light religious communities of the eighteenth century that valued women's participation and voice. Peter Vogt examines the German Moravians, a Pietist group in which, under the leadership of Count Zinzendorf (1700-176o), women assumed leadership, preached, and held ministerial office. Vogt describes how this community's theology and practice, with its emphasis on a biblical version of community and spiritual experience, opened up opportunities for women. Phyllis Mack analyzes the world of eighteenth-century British Quaker women, who were noted social reformers and activists as well as quietists seeking self-transcendence and mystical insight. These women had a strong legacy in the radicalism of the seventeenthcentury sectarians, and Mack raises questions about their gains and losses during the Enlightenment, the relationship between religion and women's political consciousness, and how a new understanding of "soul" shaped women's religious life.

Nineteenth-century women are the subject of two essays. Judylyn Ryan compares the ministry of two African American women, Maria Stewart and the fictional Baby Suggs, holy - a character created by Toni Morrison. Ryan emphasizes the vitality and significance of Christianity and African cosmology, which meet in the lives of these two women and account for their conviction that they were entitled to and capable of spiritual leadership. Ryan also uses fiction to recover the lives of enslaved African American women who left no written record of their ministry. Pamela Walker studies Catherine Booth and the women of the British Salvation Army, analyzing how the Army created a unique female ministry by drawing upon Methodist, revivalist, and holiness theologies as well as the particular culture of urban, working-class communities in Victorian England. Walker suggests comparisons 
between Booth's reading of Scripture and that of other sectarians, including Quakers and Moravians. She also explores the relationships among theology, religious practice, and culture.

The final two essays examine the early twentieth century. Yvonne Chireau explores the career of Mother Leaf Anderson, the leader of a New Orleans Spiritual church. The Spiritual churches offered diverse beliefs and practices blending Christianity with neo-African religions. Mother Leaf Anderson and her contemporaries used their authority to create spiritual practices that subverted the conventions of gender, and they established agencies to promote social justice and the well-being of their congregations. Finally, Jacqueline deVries focuses on the British women suffragists who after 1918 became preachers and campaigners for women's right to preach. DeVries continues the investigation of questions about the sources of women's spiritual authority as she traces the connections between women's preaching and political activism and the suffragists' vision of the vote as a means of achieving a more godly nation.

The idea of a history of women's preaching began to interest Beverly Kienzle and Pamela Walker when they met at Harvard Divinity School and began discussing similarities between the twelfth-century Waldensians and the nineteenth-century Salvation Army. Divided by seven hundred years and significant theological differences, the two movements nonetheless dealt with similar questions about women's authority and voice. The discussions between Kienzle and Walker led to a panel at the 1994 American Academy of Religion meetings entitled "Women's Voices in the Church" and then to Beverly Kienzle's proposal to compile a book about women preachers and prophets in the history of Christianity. The contributors to this volume also participated in a conference conceived and organized by Phyllis Mack at the Rutgers Center for Historical Analysis in November 1995: "Women Preaching in the Christian Tradition."

We owe our gratitude to many who helped shape and produce this book. Phyllis Mack and the staff at Rutgers were responsible for a successful conference; Lynn Strawbridge deserves special mention in this regard. Constance Buchanan, now at the Ford Foundation, and the faculty and staff associated with the Women's Studies in Religion Program at Harvard Divinity School brought together the editors and other contributors to the volume; the Harvard program has provided a stimulating and productive intellectual environment for scholarship on gender and religion. Stanley Holwitz, assistant director of the University of California Press, provided persuasive enthusiasm and sound advice from our first conversation with him. Others at the Press deserving our thanks are Harry Asforis, editorial assistant; Janet Mowery, copy editor; and Sue Heinemann, project editor, who guided the book 
smoothly through the phases of production. Our reviewers provided insightful comments that helped to shape and improve the book. Our thanks to Tammy Zambo for her outstanding work preparing the index and to Paul Dervis for helping us complete it. We are also grateful to the dean of arts at Carleton University and to Harvard Divinity School for their support. Kathleen Shanahan, staff assistant at Harvard Divinity School, was the person behind the scenes without whose intellect and organizational talents the book could never have been completed so quickly. Finally, we each express our gratitude to the people closest to us for their moral and intellectual support: for Beverly, Judith Rhodes, priest and preacher par excellence, Lewis Mayne, Ann Cleveland, and Edward and Kathleen Kienzle; for Pamela, Susan Whitney and their extended families, especially Elizabeth Walker.

\section{NOTES}

1. Author of four volumes of essays and letters published by her daughter, Virginia Cleveland Mayne: the best-selling $O$ Ye Jigs and Juleps (New York: Macmillan, 1962, 1989); Credos and Quips (New York: Macmillan, 1964); Flapdoodle, Trust and Obey (New York: Harper and Row, 1966); Close Your Eyes When Praying (New York: Harper and Row, 1968). The passages cited below appear in Flapdoodle, pp. 72, 76.

2. An extensive definition of the sermon in the Middle Ages is offered in Beverly Mayne Kienzle, "The Typology of the Medieval Sermon and Its Development in the Middle Ages: Report on Work in Progress," in De l'homélie au sermon: Histoire de la prédication médiévale, ed. Jacqueline Hamesse (Louvain-la-Neuve: Université Catholique de Louvain, 1993), pp. 83-88. See also The Sermon, ed. Beverly Mayne Kienzle, forthcoming in the series Typologie des sources du moyen âge (Turnhout, Belgium: Brepols, 1998).

3. Expositiones evangeliorum, ed. Beverly Mayne Kienzle and Carolyn Muessig, with the assistance of Monika Costard and Angelika Lozar, in preparation for the Corpus Christianorum Continuatio Mediaevalis; translation by Fay Martineau and B. M. Kienzle for Cistercian Publications. Articles include B. M. Kienzle, “'Operatrix in Vinea Domini': Hildegard of Bingen's Preaching and Polemics against the Cathars," Heresis 26 (1997); Barbara Newman, "Three-Part Invention: The 'Vita S. Hildegardis' and Mystical Hagiography," in Charles Burnett and Peter Dronke, eds. Hildegard of Bingen: The Context of Her Thought and Art (London: Warburg Institute, 1998).

4. Newman, "Three-Part Invention."

5. Alcuin Blamires, "Women and Preaching in Medieval Orthodoxy, Heresy and Saints' Lives," Viator 26 (1995): 135-52; Maria Adele Simonetti, ed., I sermoni di Umiltà da faenza: Studio ed edizione (Spoleto: Centro italiano di studi sull'alto medioevo, 1995), English translation in preparation by Catherine Mooney; Claire Sahlin, "Birgitta of Sweden and the Voice of Prophecy: A Study of Gender and Religious Authority in the Later Middle Ages" (Ph.D. diss., Harvard University, 1996); C. Sahlin, "The Prophetess as Preacher: Birgitta of Sweden and the Voice of Prophecy," Medieval Sermon Studies 40 (Fall 1997):29-44; Claire Waters, "Doctrine Embodied: Gender, Performance, and Authority in Late-Medieval Preaching" (Ph.D. diss., Northwestern University, 1998).

6. Some influential titles from this extensive scholarship include: William Andrews, 
Sisters of the Spirit (Bloomington: Indiana University Press, 1986); Wendy Chmielewski et al., eds., Women in Spiritual and Communitarian Societies in the United States (Syracuse, N.Y.: Syracuse University Press, 1994); Nancy Hardesty, Women Called to Witness: Evangelicial Feminism in the Nineteenth Century (Nashville, Tenn.: Abingdon Press, 1984); Brian Heeney, The Women's Movement in the Church of England, 1850-1930 (Oxford: Clarendon Press, 1988); Susan Juster, Disorderly Women: Sexual Politics and Evangelicalism in Revolutionary New England (Ithaca, N.Y.: Cornell University Press, 1995); Susan Juster and Lisa McFarlene, eds., A Mighty Baptism: Race, Gender, and the Creation of American Protestantism (Ithaca, N.Y.: Cornell University Press, 1996); Christine Krueger, The Reader's Repentance: Women Preachers, Women Writers and Nineteenth-Century Social Discourse (Chicago: University of Chicago Press, 1992); Nell Painter, Sojourner Truth: A Life, a Symbol (New York: W. W. Norton, 1996); Alex Owen, The Darkened Room: Women, Power and Spiritualism in Late Victorian England (London: Virago, 1989); Marjorie Proctor Smith, Women in Shaker Community and Worship (Lewiston, N.Y.: Edwin Mellen Press, 1985); Rosemary Radford Ruether and Rosemary Skinner Keller, eds., Women and American Religion, 3 vols. (San Francisco: Harper and Row, 1981); Deborah Valenze, Prophetic Sons and Daughters: Female Preaching and Popular Religion in Industrial England (Princeton, N.J.: Princeton University Press, 1985); and Judith Weisenfeld and Richard Newman, eds., This Far by Faith (New York: Routledge, 1996). 